\title{
Revising the History of Germanic Languages: The Concept of Germance
}

\author{
Aldo Luiz Bizzocchi \\ Center for the Research in Etymology and History of the Portuguese Language, University of Sao Paulo, Sao Paulo, Brazil \\ Email address: \\ aldo@aldobizzocchi.com.br

\section{To cite this article:} \\ Aldo Luiz Bizzocchi. Revising the History of Germanic Languages: The Concept of Germance. International Journal of Language and \\ Linguistics. Vol. 9, No. 1, 2021, pp. 1-5. doi: 10.11648/j.ijl1.20210901.11
}

Received: November 30, 2020; Accepted: January 20, 2021; Published: January 28, 2021

\begin{abstract}
This paper puts forward a new division of the history of Germanic languages, taking into account the existence of three different historical periods (prehistoric, proto-historic, and literary) in the development from Common Germanic or Proto-Germanic to modern Germanic languages, analogously to the development of Romance or Romanic languages from Vulgar Latin (also called Proto-Romanic or Proto-Romance), in which three stages can be retraced: Vulgar Latin (prehistoric), Romance (proto-historic) and literary (historical). So far, only two stages have been considered in the linguistic history of Germanic languages, namely, the Common Germanic (not documented) and the literary Germanic languages (documented since the Middle Ages). Nevertheless, the history of both families of languages is similar in most aspects, so that the three aforementioned periods can be clearly recognized in both: a period of considerable linguistic unity, although poorly or not at all documented; a period of dissolution of this unity and fragmentation into several dialects not mutually intercomprehensible; and a period of full and intense literary production and official recognition of some of these dialects, now raised to the condition of culture languages. Due to this new historiographical division, the denomination Germance is proposed for the second of the three evolutionary stages of Germanic.
\end{abstract}

Keywords: Vulgar Latin, Romance, Romance Languages, Common Germanic, Proto-Germanic, Germanic Languages, Historical Linguistics, Germance

\section{Introduction}

The Romanic, Romance, or Neo-Latin languages descend directly from Vulgar Latin (also called Proto-Romanic or Proto-Romance by Buchi and Schweickard), in a constant evolution that has never undergone a break in its continuance, that is, a rupture of the system [1]. This fact arouses the issue of knowing at what moment and for what reason the limit between Latin and its historical succedent languages is established. Similarly, Germanic languages derive from an alleged primitive Germanic, Common Germanic, or even Proto-Germanic, which, although hypothetical (or rather, not documented), since there is no written testimony of it, represents to Germanic languages the same role played by Vulgar Latin regarding Romance languages.

The aim of this paper is to revise the traditional historiographical division of Germanic languages, as it is usually presented in handbooks and works of Germanic philology and linguistics, such as those of Meillet, Karsten and Paul, Streitberg and Krahe [2-5], among others. According to the traditional conception, the history of these languages is divided into two basic periods: the prehistoric period, or primitive Germanic, and the historical period, or that of modern Germanic languages. Yet, such a division is not sufficiently specific to explain a good deal of the phenomena of phonetic evolution and lexical production of these languages, above all in what regards word loans of Latin and Romance origin.

\section{Definition of Language in Historical Linguistics}

Before continuing our discussion about the issue of how the history of languages is divided by linguists and philologists, it is prudent to define the concept of language upon which the traditional linguistic historiography is based.

As we know, the concept of "language" is an abstraction 
based on a set of real facts that are the single linguistic acts, which correspond to the speakers' thoughts and conceptualizations. These acts can only be conceived of within a society, in which they appear as communications that can only take place insofar as the speaker creates his/her expression by using certain signs (especially verbal signs, i.e., words) from which the hearer re-creates a conceptualization approximately corresponding to that of the speaker. So that this double activity on the part of the speaker and the hearer occurs, both must ascribe to the signs used, which do not have by themselves any necessary relation with their meaning, a fundamentally equal value. But, serving every time to express a new conceptualization, the sign can never have a value identical to that of its model, whence a double reason for innovation: change of the value, even with the phonetic form of the model being reproduced substantially unchanged, or change of the phonetic form of the latter as well.

This is why only with a certain approximation one can speak of identity of the signs contained in the acts of the speakers of a given linguistic community, but it is on the admission of this identity that the concept of "language" is based, which comprises the common signs to the linguistic acts of a given number of individuals or, if one prefers, the system of isoglosses gathering such linguistic acts, so that it may assume a larger or smaller scope, temporally and spatially, according to the single acts at issue. Given the nature of this concept of "language", the temporal delimitation of certain languages is made on the basis of principles other than those strictly linguistic: historical, cultural, traditional reasons make us speak as a whole of the Latin language from the $3^{\text {rd }}$ or $6^{\text {th }}$ century $\mathrm{BC}$ until the $5^{\text {th }}-6^{\text {th }}$ century $\mathrm{AD}$ and Romance languages from the $9^{\text {th }}$ century until today, and not for instance a whole language comprising both Latin and Neo-Latin traditions [6].

The concept of language given above corresponds to what Coseriu calls historical language, in a diachronic perspective, as opposed to the concept of linguistic system, which has a synchronic dimension [7]. Thus, the historical language would be a temporal succession of linguistic systems that maintain basic structural traits in common and a history with no solution of continuity or rupture.

\section{Vulgar Latin, Romances, and Modern Romance Languages}

According to Herman, the Romance languages evolved from Vulgar Latin between the $3^{\text {rd }}$ and $8^{\text {th }}$ centuries [8]. They are the historical continuation of the popular and colloquial Latin spoken by settlers, soldiers, merchants, slaves, and ordinary citizens in general of the Roman Empire, and was distinct from the learned form of the language, the so-called Classical Latin, which was spoken by the Roman aristocracy and was the variety in which the language was generally written [9].

Herman says:

"We can only glimpse a tiny amount of divergence with the actual written data. In texts of all kinds, literary, technical, and all others, the written Latin of the first five or six centuries A. D. looks as if it were territorially homogeneous, even in its 'vulgar' register. It is only in the later texts, of the seventh and eighth centuries, that we are able to see in the texts geographical differences that seem to be the precursors of similar differences in the subsequent Romance languages [10]."

Traditionally, the linguistic history of Latin is divided into three stages: Archaic Latin, Classical Latin and Low Latin or Medieval Latin. Parallel to Classical and Medieval Latin, of learned and literary character, Vulgar Latin, from which Romance languages derive, was spoken. In truth, this Vulgar Latin has never constituted a fixed and stable language. In fact, it was spoken along a large territorial extension, which included Iberia, Gaul, Italy, the Alps, Northern Africa, etc., and, in each of these regions, it had been superimposed to a pre-existent language, which is called substratum language, spoken by the autochthonous populations before the Roman conquest, and which, very often, has left traces in the phonetics, morphology, and lexicon of these populations. It is, therefore, natural that the dialectal diversity of Vulgar Latin be quite significant. Nevertheless, as long as the Roman Empire survived, the communication among the various provinces remained sufficiently intense as to prevent dialectal divergences to become so deep as to break the possibility of mutual understanding. The noticeable exception was Sardinian, which, thanks to its geographical isolation, is generally considered to be the most conservative Romance language and became linguistically independent from Vulgar Latin possibly as early as by the first century BC.

On the other hand, since the definitive ruin of the Empire, in the $5^{\text {th }}$ century $\mathrm{AD}$, the communications had become more difficult, the commercial relationships among the provinces had ceased and the literary culture, another highly important factor of union among Latin-speakers, had experienced a period of extreme decadence. Let us add to this the invasion of the Romanized territories by Germanic peoples who, although in many cases adopting Latin - or rather, its local dialects -, brought to these dialects their own linguistic habits, contributing thus to increase the linguistic diversification between regions [11]. Germanic languages represented, in this way, superstratum languages in regard to Vulgar Latin of the invaded provinces. Thus begins a new period in the history of language, in which it is no longer convenient to speak of a Vulgar Latin, but a Romance, or, rather, various Romances.

The form of Vulgar Latin that evolved into the Romance languages was spoken alongside the written Classical Latin used in official and formal occasions. The distinctions between the two varieties of Latin can be thus considered as sociolinguistic and register variants, so much so that they were mutually intelligible since they were considered one and the same language.

Yet, during the so-called Romance period (approximately $6^{\text {th }}$ to $9^{\text {th }}$ centuries $\mathrm{AD}$ ), Latin became a dead language. According to Herman, "the Romanized people of Europe could no longer understand texts that were read aloud or 
recited to them" [8]. This means that Latin was no more a first language but a foreign language that had to be learned.

The Romance period begins with the fall of the Western Roman Empire and it extends until the moment when some of its dialects ascend to the position of languages of literature and culture, with the other dialects ceasing to be seen as dialects of Latin or Romance, but as regional varieties of the literary languages used in the territories where they are spoken.

From the $4^{\text {th }}$ to $8^{\text {th }}$ centuries, many changes in phonology, morphology, syntax, and lexicon accumulated so as to produce local varieties notably different from one another. The differences between dialects tended to grow the more geographically separated they were, which made mutual intelligibility between speakers of distant communities quite difficult [12].

Thus, the speakers of that time themselves used to distinguish between latine loqui (to speak Classical and literary Latin), romanice loqui (to speak the colloquial Romances), and barbarice loqui (to speak languages other than Latin or Romance, such as Germanic, for instance) [13].

The Romance period has left almost no documents because, especially from the $5^{\text {th }}$ to the $8^{\text {th }}$ century, period known as the Dark Ages, the literate culture had practically disappeared. The few documents of that phase were written in Medieval Latin, a continuation of Classical Latin developed above all by the Catholic Church.

Between the $9^{\text {th }}$ and $13^{\text {th }}$ centuries, some Romances began to be written formally, thus supplanting Latin as a literary and official language. For example, the first French-written document is the Oaths of Strasbourg (842 AD), and the first testimony of Italian vernacular was the Placiti Cassinesi, (960-963). But the Italian language only started to be systematically written in the $13^{\text {th }}$ century, by poets such as Giacomo da Lentini and Dante Alighieri.

The Latin linguistic history can thus be didactically divided into three large periods: one Vulgar Latin or Proto-Romanic period (until $\pm 600 \mathrm{AD}$ ), one Romance period, and one Neo-Latin period, which in turn will be divided into Old $\left(9^{\text {th }}\right.$ to $11^{\text {th }}$ century), Middle ( $12^{\text {th }}$ to $15^{\text {th }}$ century) and Modern (from the $16^{\text {th }}$ century onwards).

\section{Common Germanic, Germances, and Modern Germanic Languages}

A similar historiographical division can be applied to the domain of Germanic languages. It is true that traditional works on Germanic philology only distinguish two periods, the one called Common Germanic or Proto-Germanic, and the other in which the written testimonies of Germanic dialects begin to show, giving birth to the literary period. Notwithstanding, if we observe more attentively the history of Germanic peoples, we will see that much of what was said about the Latin tradition in its various phases applies to Germanic as well. First of all, primitive or Proto-Germanic, although never documented, for it has been reconstructed by comparison to the other Indo-European languages and through the evidence of its succedent languages, presents an archaic phase, commonly denominated Pre-Germanic, posited by Germanicists to explain the transition between Indo-European and Germanic proper, and a phase of great linguistic stability, in which the main traits of Germanic languages, such as Grimm's law consonant shift, are already consolidated: the aforementioned Common Germanic. Similarly to Vulgar Latin, Common Germanic has probably never been a unitary language, but rather a set of dialects of Indo-European origin bringing common isoglosses, which approached each other and, at the same time, distinguished them from the other Indo-European dialects: Italic, Celtic, Greek, Baltic dialects, etc. At this stage, such dialects were still sufficiently close, since the tribes that spoke them were circumscribed to a relatively little extensive territory. In this case, the exception was the Eastern Germanic dialects, whose most remarkable example is Ulfila's Gothic from the $4^{\text {th }}$ century AD. Nonetheless, the Eastern branch may be derived from the Northern one already in the $1^{\text {st }}$ century AD. The language of this period essentially still reflects the Common Germanic stage.

However, above all from the $5^{\text {th }}$ century onwards, impelled by the invasion of Attila's Huns who came from the East, the Germanic peoples progressively scattered, especially towards the West and South, with some tribes having invaded the Roman territory and blended with the aboriginal peoples, as in the case of the Franks in Gaul. From that point on, the linguistic diversity among the Germanic peoples also begins to intensify, so that we can say that this phase of their history compares to the Romance period, which is why one advocates here denominating the Germanic of that time Germance, by analogy to Romance. ${ }^{1}$

The Germance period begins, therefore, with the great wave of invasions and incursions carried out by Germanic peoples into the Roman Empire (especially during the $4^{\text {th }}$ and $5^{\text {th }}$ centuries) and it lasts until the beginning of the literary tradition of Germanic languages, which corresponds to the emergence of Old English (Anglo-Saxon) in the $8^{\text {th }}$ century and Old High German in the $8^{\text {th }}-9^{\text {th }}$ centuries, among others $[14,15]$.

In short, one proposes dividing the history of the Germanic linguistic family into three distinct stages, namely: one Common Germanic period, one Germance period, and one Neo-Germanic period.

The postulation of an intermediate stage between Common Germanic and the historically documented Germanic languages, which is being here denominated Germance period, is, in my opinion, highly important to the study of Germanic linguistics, since many phonetic, morphological, and lexical phenomena commonly assigned to Common Germanic in actuality occurred in the Germance period, as, for example, the passage from Germanic $\bar{e}$ (also called $\bar{e}_{1}$ ) to $\bar{æ}$ and later (in the Neo-Germanic period) to $\bar{a}$ (for example, Germanic *lètan- > Old High German lāzzen), the emergence of $\bar{e}_{2}$, the

\footnotetext{
1 Analogously to the words existing in the several European languages to express the concept of Romance (for example, French roman, Italian romanzo, German Romane, Spanish and Portuguese romance, etc.), the word Germance, proposed here, could be translated into those languages as follows: French german, Italian germanzo, German Germane, Spanish and Portuguese germance, etc.
} 
phenomenon of vowel breaking (for example, Germanic *gulpam > English gold), the disappearance of the dual and declensions, and the borrowing of Greek and Latin words, contemporary to the intensification of the contact between Romans and Germanic peoples.

Greek and Latin, the only literary languages of that time, had for this very reason a superior hierarchic status regarding vulgar languages, both Romance and Germanic. The vulgar languages have developed as literary languages according to the Greco-Latin model. Thus, the kinship existing between Classical Latin and Romance languages does not make the latter more susceptible to the influence of the classical languages than Germanic languages would be, exactly because this kinship is indirect, since, as seen before, Romance languages proceed from Vulgar, not from Classical Latin. In this sense, the effect of the Greco-Latin influence is exactly the same on both linguistic families. Let us, then, schematize the evolutionary process of these languages and the relationship existing between them and the classical languages as follows (Figure 1):

$$
\text { Classical languages }\left\{\begin{array}{l}
\text { Classical Greek* } \\
\text { Classical Latin * } \\
\text { Low (Medieval) Latin* }
\end{array}\right.
$$

\begin{tabular}{|c|c|c|c|}
\hline \multicolumn{2}{|c|}{ Vulgar Latin** } & \multicolumn{2}{|c|}{ Common Germanic** } \\
\hline$\downarrow$ & $\begin{array}{l}\text { Western: Iberian } \\
\text { Romance, Italo- } \\
\text { Western Romance, } \\
\text { etc. }\end{array}$ & $\downarrow$ & $\begin{array}{l}\text { Western: Anglian, } \\
\text { Anglo-Saxon, } \\
\text { Old Saxon, } \\
\text { Frankish, Bavarian, }\end{array}$ \\
\hline $\begin{array}{l}\text { Romance } \\
* * *\end{array}$ & $\begin{array}{l}\text { Northern: Gallo-R., } \\
\text { Rhaeto-Romance } \\
\text { Eastern: Dacian, } \\
\text { Sardinian, } \\
\text { Dalmatian }\end{array}$ & $\begin{array}{l}\text { Germance } \\
* * *\end{array}$ & $\begin{array}{l}\text { Frisian, Alemannic, } \\
\text { etc. } \\
\text { Northern: Old Norse } \\
\text { Eastern: Gothic, } \\
\text { Burgundian }\end{array}$ \\
\hline $\begin{array}{l}\quad \downarrow \\
\text { Romance } \\
\text { languages } \\
* * * *\end{array}$ & $\begin{array}{l}\text { Portuguese } \\
\text { Galician } \\
\text { Spanish } \\
\text { Catalan } \\
\text { French } \\
\text { Occitan } \\
\text { Italian } \\
\text { Venetian } \\
\text { Romansh } \\
\text { Romanian }\end{array}$ & $\begin{array}{l}\quad \downarrow \\
\text { Germanic } \\
\text { languages } \\
* * * *\end{array}$ & $\left\{\begin{array}{l}\text { Norwegian } \\
\text { Neo-Norwegian } \\
\text { Swedish } \\
\text { Danish } \\
\text { English } \\
\text { Scots } \\
\text { German } \\
\text { Dutch } \\
\text { Luxembourgish } \\
\text { Icelandic }\end{array}\right.$ \\
\hline
\end{tabular}

Figure 1. The historical division of both Romance and Germanic languages in relation to the classical languages as proposed here.

\footnotetext{
* classical languages $\rightarrow$ influence the learned norm of vulgar languages

** not directly documented languages

$* * *$ little documented languages $\left(5^{\text {th }}\right.$ to $9^{\text {th }}$ century)

$* * * *$ fully documented languages (from the $8^{\text {th }}-9^{\text {th }}$ century onwards)
}

The Romance/Germance period has a fundamental importance to the genesis of the Western Civilization, since it is exactly at this stage that the crossing between the two basic cultures that form this civilization takes place: the Greco-Roman-Christian culture and the Germanic culture. During the primitive Latin/Germanic period, most of the lexical fund of these languages was autochthonous, with a few words borrowed from Celtic or Greek (in the case of Latin). In the Romance/Germance phase, the exchange of cultural and ideological values (Christianity, feudalism, chivalrousness, courtly love, customary law, etc.) has implied the exchange of words. At that time, the various Romances were populated by Germanic words (for example, French garder < Germance wardan < Germanic *wardōn-, French danser < Frankish Germance *dintjan < Germanic *dantison-, etc.), at the same time that Germances receive Romance lexical contributions (for example, English cup < Romance cuppa $<$ Latin cuppa, English dish $<$ Romance discu $<$ Latin discus/um, etc.) [16]. ${ }^{2}$

\section{Conclusion}

Both the Latin or Romance and the Germanic linguistic traditions have parallel and interconnected histories. In fact, although Latin is a well documented language which has had a tremendous influence on the Western Civilization and the modern Western European languages, namely the Neo-Latin and Neo-Germanic ones, whereas Proto-Germanic is a "barbaric" not documented language that only left fragments of runic inscriptions, we can say that the situation of Vulgar Latin was not so different from that of Common Germanic, since few and sparse documents written in the sermo vulgaris have remained. And it is from Vulgar and not Classical Latin that the modern Romance languages descend. Both Vulgar Latin and Common Germanic were sets of dialects that maintained most of their traits in common (i.e. common isoglosses), which were little by little being lost as the distance of the speaking communities was growing, and consequently their intercommunication was decreasing.

Both had early dissensions, that is, speeches that soon split off from the common language: Sardinian, in relation to Vulgar Latin, and Gothic regarding Common Germanic. These splits probably occurred both as early as by the $1^{\text {st }}$ century AD.

Therefore, both linguistic families knew a stage of considerable unity, a stage of dissolution of this unity when pre-literary languages emerged, and finally a stage when some of these languages began to produce literature and be considered official languages of some kingdoms. And these stages were practically simultaneous in both families.

So, as said before, the postulation of a linguistic stage between Common Germanic and the Germanic languages that we know today is fundamental to the explanation and understanding of a number of phenomena which, otherwise, are analyzed and interpreted in a much more complex and, sometimes, mistaken way.

\footnotetext{
2 In fact, there have been two waves of loans towards the Germanic family: the first one, from Vulgar Latin to Common Germanic, occurred approximately between the $1^{\text {st }}$ century $\mathrm{BC}$ and the $4^{\text {th }}$ century $\mathrm{AD}$, from which quite few loanwords result, and the second one, much more intense, between Romances and what I call here Germances $\left(5^{\text {th }}-6^{\text {th }}\right.$ century $\mathrm{AD}$ until the consolidation of the current literary languages) [17].
} 


\section{References}

[1] Buchi, E. and Schweickard, W., "Romanistique et étymologie du fonds lexical héréditaire: du REW au DÉRom (Dictionnaire Étymologique Roman)", in Alén Garabato, C. et al. (ed.) La Romanistique dans Tous ses États. Paris: L'Harmattan, 2009, p. 101.

[2] Meillet, A., Caractères Généraux des Langues Germaniques. Paris: Les Cent Chemins, 2017.

[3] Karsten, T. E. and Paul, H., Die Germanen: Eine Einfu hrung in die Geschichte ihrer Sprache und Kultur. Berlin; Boston: De Gruyter Mouton, 2017.

[4] Streitberg, W., Urgermanische Grammatik. Einführung in das Vergleichende Studium der Altgermanischen Dialekte. München: Hanse, 2016.

[5] Krahe, H., Lingüística Germánica. Translated by Maria Teresa Zurdo. Madrid: Ediciones Cátedra, 2007.

[6] Pisani, V., Introduzione alla Linguistica Indeuropea. Turin: Rosenberg \& Sellier, 1983.

[7] Coseriu, E., Teoria da Linguagem e Lingüística Geral. Rio de Janeiro/São Paulo: Presença/EDUSP, 1979.

[8] Herman, J., Vulgar Latin. Translated by Roger Wright. University Park: Pennsylvania State University Press, 2000, pp. 96-115.

[9] Zhang, H., From Latin to the Romance languages: A normal evolution to what extent? Quarterly Journal of Chinese Studies, 3 (4): 2015, pp. 105-111.

[10] Herman, J., Vulgar Latin. Penn State Press, 2010, p. 117.

[11] Harris, M. and Vincent, N., Romance Languages. London: Routledge, 2001.

[12] Price, G., The French Language: Past and Present. London: Grant and Cutler, 1984.

[13] Ilari, R., Lingüística Românica. São Paulo: Ática, 1997, p. 50.

[14] Baugh, A. C. and Cable, T., A History of the English Language. $6^{\text {th }}$ ed. London: Routledge, 2013.

[15] Scherer, W., Zur Geschichte der Deutschen Sprache. Amsterdam: John Benjamins, 1995.

[16] Falk, H. and Torp, A., Etymologisk Ordbog over det Norske og det Danske Sprog, Vol. 1. Oslo: Bjørn Ringstrøms Antikvariat, 1991.

[17] Duden, Das Herkunft Wörterbuch: Etymologie der Deutschen Sprache. Mannheim: Dudenverlag, 2007, pp. 286-297. 